\title{
PENYELESAIAN PEMBIAYAAN MURĀBAHAH BERMASALAH DI BMT MIKAT AL-KHIDMAH PURWOREJO
}

\author{
Muhajir, Fathudin, Hary Listyadi \\ Sekolah Tinggi Agama Islam An-Nawawi Purworejo \\ muhajirmadruslam@gmail.com
}

Naskah masuk:18-08-2021, direvisi:02-09-2021, diterima:08-09-2021, dipublikasi:18-09-2021

\begin{abstract}
ABSTRAK
Adanya pembiayaan bermasalah dikarenakan banyak mitra/nasabah yang macet dalam melakukan pembayaran. Pembiayaan bermasalah yang ada di BMT Mikat Al-Khidmah Purworejo ini merupakan bukan persoalan biasa, dan perlu adanya Penyelesaian yang serius dari BMT Mikat Al-Khidmah. Maka dari itu peneliti mengambil judul ini dengan tujuan ingin mengetahui bagaimana penyelesaian pembiayaan bermasalah yang dilakukan oleh BMT Mikat Al-Khidmah serta bagaimana pandangan Hukum Islam terhadap cara penyelesaian yang dilakukan oleh BMT Mikat Al-Khidmah. Penelitian ini termasuk jenis penelitian lapangan (field research) dengan mengambil objek penelitian di BMT Mikat Al-Khidmah Purworejo. Sumber data terdiri dari data primer dan sekunder. Data primer diperoleh langsung melalui observasi, wawancara dan dokumentasi. Sementara data sekunder merupakan informasi lebih lanjut yang berkenaan dengan problem penelitian dari literatur atau penelitian terdahulu. Metode pengumpulan data yang digunakan dalam penelitian ini adalah dengan cara metode observasi, wawancara, dan dokumentasi. Selanjutnya analisis data dengan menggunakan metode analisis deskriptif, yaitu menganalisis data yang sudah terkumpul kemudian dianalisis untuk mengetahui Penyelesaian pembiayaan Murābahah bermasalah di BMT Mikat AlKhidmah.
\end{abstract}

Kata Kunci: Hukum Islam, Pembiayaan, Murābahah

\begin{abstract}
The existence of financing is problematic because many partners / customers get stuck in making payments. This problematic financing at BMT Mikat Al-Khidmah Purworejo is not an ordinary problem, and it needs serious handling from BMT Mikat Al-Khidmah. Therefore, the researcher took this title with the aim of wanting to know how the handling of problematic financing was carried out by BMT Mikat Al-Khidmah and how the Islamic Law views the handling methods carried out by BMT Mikat AlKhidmah. This research is a type of field research (field research) by taking the object of research at BMT Mikat Al-Khidmah Purworejo. Data sources consist of primary and secondary data. Primary data is obtained directly through observation, interviews and documentation. Meanwhile, secondary data is further information relating to research problems from the literature or previous research. Data collection methods used in this research are observation, interview, and documentation methods. Furthermore, data analysis using descriptive analysis method, namely analyzing the data that has been collected and then analyzed to determine the handling of problematic Murābahah financing at BMT Mikat Al-Khidmah.
\end{abstract}

Keywords: Islamic Law, Financing, Murābahah 


\section{PENDAHULUAN}

Salah satu Lembaga Keuangan Syariah (LKS) adalah Baitul Maal Wa Tamwil (BMT) atau Koperasi Jasa Keuangan Syariah (KJKS). BMT adalah organisasi bisnis yang juga berperan sosial. BMT merupakan lembaga keuangan mikro yang penting di Indonesia, dapat dilihat dari kinerja dalam melayani masyarakat maupun jumlah anggotanya. Salah satu keunggulan BMT adalah daya tahan yang cukup kuat atas goncangan perekonomian di Indonesia.

Ketika Indonesia mengalami masa-masa sulit selama krisis ekonomi dan moneter, BMT banyak berperan hingga ke lapisan bawah. Dengan kata lain, BMT sering melakukan pendekatan dan bantuan kepada kalangan usaha kecil dan menengah untuk mendorong kemajuan usaha mereka. BMT dilihat dari fungsinya merupakan lembaga intermediasi keuangan antara pemilik dana (surplus unit) dan peminjam (defisit unit) seperti yang dikutip oleh (Ridwan, 2004: 150-159), yang membahas tentang BMT beroperasi berlandaskan prinsip-prinsip ekonomi Islam yang pada intinya menerapkan bahwa dana pada dasarnya merupakan salah satu alat produksi untuk meningkatkan kesejahteraan bersama, bukan orang atau perorang. BMT tumbuh dari keinginan dan prakarsa masyarakat sendiri, sehingga BMT merupakan salah satu jenis kelompok swadaya masyarakat yang bekerja dari, oleh dan untuk anggota.

BMT sebagaimana yang dipahami orang sebagai lembaga ekonomi kaum akar rumput, yang dibentuk atas prakarsa dan swadaya masyarakat dengan segala kelebihan dan kelemahannya, terbukti sangat efektif untuk menolong pengusaha kecil dan mikro dalam mengakses sumber dana pembiayaan.

Sejalan dengan pengertian diatas, BMT Al-Khidmah membantu dan memberikan pelayanan kepada masyarakat dalam hal penyimpanan dana dan juga pembiayaan. Masyarakat Purworejo yang memiliki penghasilan menengah ke atas membuat BMT AlKhidmah sangat dibutuhkan untuk memenuhi kebutuhan mereka dalam penyimpanan dana maupun pembiayaan modal kerja. Produk-produk BMT Al-Khidmah Purworejo sangatlah beragam, mulai dari tabungan, simpanan berjangka (deposito), pembiayaan, dan lain sebagainya. Produk-produk ini memiliki bermacam-macam akad yang berbeda-beda yang dapat disesuaikan dengan kebutuhan masing-masing anggota (Antonio, 2001: 128).

Dampak mewabahnya virus Covid 19, membuat para mitra yang melakukan pembiayaan mengalami penurunan pendapatan. Sehingga, hal ini berakibat pada terkendalanya para mitra pembiayaan dalam melakukan pembayaran cicilan pada pihak lembaga keuangan. Hal ini pun juga dirasakan oleh para mitra/nasabah BMT Mikat AlKhidmah Purworejo. Jika di Bank-Bank yang berada di bawah nauangan BUMN mendapat suplai dana dari pemerintah, namun tidak demikian untuk dilembaga keuangan setingkat BMT.

Dari uraian di atas terlihat bahwa pembiayaan merupakan salah satu aset penting dalam suatu perbankan. Namun dengan adanya virus Covid 19 pembiayaan banyak yang terkendala dan tentunya ini menjadi masalah bagi pihak BMT. Untuk menjalankan Pembiayaan dengan baik maka diperlukan adanya strategi penanganan pembiayaan bermasalah pada BMT Mikat Al-Khidmah. Semakin berkembangnya BMT Al- Khidmah tidak terlepas dengan masalah yang dihadapai. Lambatnya angsuran yang diterima oleh BMT 
menjadi alasan yang klasik bagi BMT. Persoalan ini sudah menjadi hal yang umum tiap terjadi akad-akad pembiayaan walaupun tidak semua peminjam selalu bermasalah.

Secara bahasa murābahah berasal dari kata ribh yang bermakna tumbuh dan berkembang dalam perniagaan. Dalam istilah Syariah, konsep murābahah terdapat berbagai formulasi definisi yang berbeda-beda menurut pendapat para ulama', diantaranya menurut pendapat Utsmani murābahah merupakan salah satu bentuk jual beli yang mengharuskan penjual memberi informasi kepada pembeli tentang biaya-biaya yang dikeluarkan untuk mendapatkan komoditas (harga pokok penjualan) dan tambahan profit yang diinginkan yang tercermin dalam harga jual (Nawawi, 2012: 91).

Murābahah dalah prinsip jual beli dimana harga jualnya terdiri dari harga pokok yang ditambah nilai keuntungan (ribhun) yang disepakati. Sedangkan murābahah didefinisikan oleh para fuqaha sebagai penjualan barang seharga biaya/harga pokok (cost) barang tersebut ditambah mark-up atau margin keuntungan yang disepakati. Karakteristik murābahah adalah bahwa penjual harus memberi tahu pembeli tentang mengenai harga pembelian produk dan menyamakan jumlah keuntungan yang ditambah pada biaya (cost) tersebut (Wiroso, 2005: 13).

Dalam daftar istilah buku himpunan fatwa DSN (Dewan Syariah Nasional) dijelaskan bahwa yang dimaksud dengan muräbahah adalah menjual suatu barang dengan menegaskan harga belinya kepada pembeli dan pembeli membayarnya dengan harga yang lebih sebagai laba. Berdasarkan PSAK 59 tentang Akuntansi Perbankan Syariah paragraf 52 dijelaskan bahwa murābahah adalah akad jual beli barang dengan menyatakan harga perolehan dan keuntungan (margin) yang disepakati oleh penjual dan pembeli (Wiroso, 2005: 13).

Dalam penyaluran pembiayaan berdasarkan akad murābahah, Undang-Undang Perbankan Syaria'ah memberikan penjelasan bahwa yang dimaksud dengan akad murābahah adalah akad pembiayaan suatu barang dengan menegaskan harga belinya kepada pembeli dan pembeli membayarnya lebih sebagai keuntungan yang disepakati (Wangsawidjaja, 2005: 200).

Murābahah dalam fikih Islam yang berarti "suatu bentuk jual beli tertentu ketika penjual menyatakan biaya perolehan barang, meliputi harga barang dan biaya-biaya lain yang dikeluarkan untuk memperoleh barang tersebut, dan tingkat keuntungan (margin) yang diinginkan. Pembiayaan murābahah dalam istilah teknis perbankan diartikan sebagai "suatu pembiayaan dengan suatu perjanjian yang disepakati antara bank Syariah dengan nasabah, dimana bank menyediakan pembiayaan untuk pembelian bahan baku atau modal kerja lainnya yang dibutuhkan nasabah yang akan dibayar kembali oleh nasabah sebesar harga jual bank (harga beli bank ditambah margin keuntungan) pada waktu yang ditetapkan" (Ascarya, 2007: 82).

Dari pengertian di atas dapat disimpulkan bahwa murābahah yaitu prinsip jual beli dimana harga jualnya terdiri dari harga pokok yang ditambah keuntungan yang telah disepakati bersama. Akad jual beli dimana BMT bertindak sebagai penjual dan nasabah bertindak sebagai pembeli, dengan perantara pihak ketga (supplier), BMT terlebih dahulu memesan barang yang diinginkan nasabah yang proses pengambilan atas barang tersebut dilakukan oleh nasabah sebagai agen BMT dan proses pembayarannya dilakukan secara tunai, tangguh ataupun dicicil sesuai dengan jangka waktu tertentu yang telah disepakati bersama. 
Akad murābahah mempunyai resiko yang lebih kecil dibandingkan dengan akad yang berbasis bagi hasil semisal akad musyarakah dan akad mudharabah. Berbeda dengan akad mudharabah dan akad musyarakah yang mengenal loss sharing/bagi rugi, dalam akad murābahah tidak dikenal loss sharing. Hal ini dikarenakan tersebut hubungan bank dengan nasabah dalam akad murābahah hanya sebatas debitur-kreditur, bukan hubungan kemitraan seperti pada akad musyarakah atau akad mudharabah. Itulah kenapa akad murābahah lebih banyak diminati dibandingkan akad-akad lainnya.

\section{METODE PENELITIAN}

\section{Jenis dan sifat Penelitian}

Penelitian dalam kajian penelitian ini adalah termasuk jenis penelitian lapangan (Field Research), (Soekanto, 1984: 10), yaitu terjun langsung ke lapangan dengan mencari dan mengumpulkan data sebanyak-banyaknya yang ada BMT. Penelitian ini menggunakan data dan sumber informasi lapangan yang bertujuan memperoleh data-data yang diperoleh dari medan terjadinya gejala-gejala. Penelitian ini mengambil di BMT Mikat Al-Khidmah dengan memfokuskan pada analisisi penanganan pembiayaan murābahah bermasalah.

\section{Jenis Data}

Dalam penelitian ini jenis data yang digunakan adalah data yang terdiri dari:

a. Data primer adalah data langsung dari sumber pertama (Ibrahim, 2018: 68). Dalam hal ini Peneliti menggunakan data yang bersumber dari hasil interview secara langsung dengan pengelola BMT Mikat Al-Khidmah Kabupaten Purworejo.

b. Data sekunder dalam penelitian ini adalah data yang didapatkan bukan secara langsung tetapi mengandung informasi, fakta dan relevan dengan penelitian penyusun. Menurut Bungin dalam bukunya Metodologi Penelitian Kualitatif menyebutkan data sekunder adalah data yang diperoleh dari sumber kedua atau sumber sekunder. Data sekunder menurutnya terbagi menjadi dua bentuk yaitu pertama, internal data, adalah data yang tertulis dalam sumber data sekunder, kedua, eksternal data, adalah data yang diperoleh dari sumber luar seperti, data sensus (Ibrahim, 2018: 68). Dalam penelitian ini Peneliti menggunakan data yang membahas profil BMT Mikat Al-Khidmah Purworejo.

\section{Sumber Data}

a. Sumber data primer

Data primer yang dimaksud yaitu data yang diperoleh dari observasi, peneliti memperoleh data dengan pengamatan secara langsung dari sumber penelitian yang diamati. Dalam penelitian ini Peneliti memperoleh informasi secara langsung dari pihak BMT Mikat Al-Khidmah melalui wawancara, observasi dan dokumentasi.

b. Sumber data sekunder

Data sekunder yaitu data yang diperoleh dari dokumen, buku-buku dan arsip-arsip yang berkaitan dengan topik yang akan diteliti. Dalam penelitian ini menggali beberapa teoriteori yang berhubungan dengan pokok permasalahan. Dalam penelitian ini data yang diambil melalui kepustakaan yaitu seperti buku yang berhubungan dengan tugas akhir ini. Penelitian ini berupa formulir dan brosur-brosur BMT Mikat Al-Khidmah Purworejo. 


\section{Metode Pengumpulan Data}

a. Wawancara

Peneliti menggali dan mengumpulkan data penelitian dengan melakukan pertanyaan dan pernyataan secara lisan untuk dijawab oleh responden Peneliti. Wawancara yang dilakukan Peneliti kepada bagian-bagian BMT Mikat yaitu: Manager BMT, Kepala Cabang, dan Kepala Pemasaran BMT Mikat Al-Khidmah Purworejo.

b. Observasi

Peneliti terlibat secara langsung dengan objek penelitian dan ikut dalam proses pengumpulan kelengkapan data yang diperlukan. Dalam hal ini Peneliti mengamati langsung kinerja di BMT Mikat Al-Khidmah Purworejo.

c. Dokumetasi

Metode dokumentasi adalah cara pegumpulan data dengan mencari data mengenai halhal yang berupa catatan-catatan suatu peristiwa yang ditinggalkan baik, tertulis maupun tidak tertulis, yaitu berupa catatan wawancara dan brosur-brosur. Dalam hal ini Peneliti mengumpulkan data berupa Profile Company, catatan wawancara dengan karyawan BMT Mikat, dan brosur-brosur BMT Mikat Al-Khidmah Purworejo.

d. Metode Analisis Data

Dalam penelitian ini Peneliti menggunakan metode deskriptifanalisis. Analisis deskriptif bertujuan untuk memberikan deskripsi mengenai subyek penelitan berdasarkan data yang diperoleh dari kelompok subyek yang diteliti. Data-data yang diperoleh kemudian Peneliti analisis dengan mengaitkan antara penanganan pembiayaan bermasalah di BMT Mikat Al-Khidmah Purworejo dengan teori dan konsep yang ada.

\section{HASIL DAN PEMBAHASAN}

\section{Pembiayaan Murābahah di BMT Mikat Al-Khidmah}

Produk murābahah merupakan salah satu produk pembiayaan unggulan yang ada di BMT Mikat al-Khidmah. Prinsip dasar BMT adalah menghimpun dana darimasyarakat dan menyalurkan dana dari dan untuk masyarakat. Untuk itu, BMT sebagai lembaga keuangan dalam bentuk Koperasi Simpan Pinjam Unit Syariah (KSPUS) tidak lepas dari prinsip operasional tersebut, diantaranya melalui pembiayaan murābahah, sebagai langkah untuk menyalurkan dana yang dihimpun oleh BMT.

Seiring dengan berkembangnya pembiayaan yang cepat, pastinya terdapat pembiayaan bermasalah.Untuk itu BMT Mikat Al-Khidmah harus terus menjaga kinerja usahanya agar tidak terhambat. BMT Mikat Al-Khidmah juga melakukan strategi untuk menangani pembiayaan bermasalah yaitu dengan cara pencegahan. Adapun langkah-langkahnya sebagai berikut:

a. Analisa Pengajuan Pembiayaan Sesuai dengan Persyaratan

Setiap permohonan pembiayaan yang diajukan oleh calon anggota atau nasabah, tentu harus dilakukan penilaian secara seksama oleh pihak BMT Mikat Al-Khidmah. Syaratsyarat yang telah ditentukan oleh pihak BMT Mikat Al-Khidmah merupakan prosedur awal yang harus diserahkan oleh calon anggota atau calon penerima pembiayaan.Kelengkapan ini menjadi tolak ukur pihak anggota untuk melakukan pengajuan pembiayaan.

Adapun syarat-syarat dalam mengajukan pembiayaan di BMT Mikat Al-Khidmah sebagai berikut: 
1) Menjadi Anggota di BMT Mikat Al-Khidmah. Untuk mengajukan pembiayaan, nasabah yang belum masuk menjadi anggota BMT Mikat Al-Khidmah, calon nasabah diwajibkan untuk menjadi anggota terlebih dahulu. Karena BMT adalah lembaga yang berdiri dalam bentuk koperasi Syariah. Oleh karena itu, nasabah harus menjadi anggotanya agar bisa melakukan pembiayaan atau peminjaman dana.

2) Foto copy KTP suami-istri 1 lembar. Foto copy KTP suami-istri merupakan salah satu syarat kelengkapan dalam mengajukan pembiayaan dan lazim digunakan dalam lembaga keuangan/perbankan. BMT dalam hal ini harus mengetahu secara rinci calon nasabahnya.

3) Foto copy Kartu Keluarga (KK) 1 lembar. Foto copy KK merupakan syarat kelengkapan yang harus dilengkapi oleh nasabah dalam mengajukan pembiayaan atau pinajaman dana di BMT.

4) Foto copy surat nikah (jika sudah menikah) 1 lembar. Foto copy surat nikah adalah kelengkapan yang dilengkapi oleh nasabah sebanyak 1 lembar.

5) Rekening listrik dan air. Rekening listrik dan air merupakan syarat kelengkapan yang dilengkapi oleh nasabah. Rekening ini harus yang asli dan tidak foto copy-an. Pihak BMT meminta nasabah untuk menunjukkan rekening yang asli, agar tidak terjadi penipuan.

6) Foto copy jaminan 1 lembar. Foto copy jaminan yaitu berupa BPKB, STNK atau Sertifkat. Ini merupakan syarat dalam pengajuan pembiayaan. Setelah itu BMT akan meminta foto barang jaminan tersebut dengan jelas dan rinci (Widianto, 2020).

Sebelum dilakukan pencairan pembiayaan, pihak BMT Mikat Al-Khidmah Purworejo melakukan analisa penilaian pembiayaan agar BMT yakin bahwa pembiayaan yang diberikan akan kembali dengan lancar. Penilaian pembiayaan yang dilakukan BMT Mikat Al-Khidmah secara umum yaitu dengan analisis 5C, sebagai berikut:

1) Character (karakter nasabah). Pihak BMT bisa melihat dan mengamati dari watak atau sifat kepribadian yang dimiliki dalam sehari-hari oleh anggotanya. Akan lebih baik jika dalam melakukan sebuah pembiayaan didasari dengan kepercayaan dari masing-masing pihak. Untuk mengetahui karakter anggota atau nasabahnya, pihak BMT akan melaukan survey dengan tetangganya atau dengan orang yang bekerja sama dalam kegiatan usahanya yaitu berupa tanya jawab dengan menanyakan cara anggota tersebut dalam berinteraksi dengan warga. Pihak BMT akan melakukan pengecekan karakter dan menyimpulkan bagaimana karakter anggota tersebut, bagaimana moral, sikap, budi pekerti dan diharapkan anggota akan mengembalikan dana secara tepat waktu.

2) Capacity (kemampuan dalam membayar). Kemampuan anggota untuk mengembalikan pinjaman pokok atau margin pembiayaan.BMT Mikat Al-Khidmah akan melihat cara kemampuan anggota dalam mengelola usahanya untuk mengembalikan pinjamannya. Dalam hal ini BMT juga menilai kemampuan anggotanya dengan melakukan tinjauan dan analisis terhadap kelayakan dan pertumbuhan usahanya. Dengan demikian, pihak BMT bisa memastikan bahwa anggotanya untuk membayar pinjamannya.

3) Capital (modal). Modal yang dimiliki oleh anggota itu sendiri, biasanya dilihat dari pendapatan perbualan dikurangi pengeluarannya. BMT akan melihat modal yang dimiliki anggota untuk membayar pinjamannya. Penilaian ini bertujuan untuk mengetahui apakah usaha yang dijalankan oleh anggota cukup baik, dalam artian ini mampu untuk mencukupi kebutuhan keluarganya dan mampu untuk membayar 
kembali pinjaman kepada BMT dan mampu berkembang sehingga usahanya semakin besar.

4) Condition (kondisi usaha). Kondisi usaha yang dijalankan oleh anggota harus baik, baik dalam artian ini mampu mencukupi kebutuhan keluarga dan mampu membayar kembali pinjaman kepada BMT. Apalagi akan mendapatkan pembiayaan oleh BMT Mikat Al-Khidmah, maka kondisi usaha tersebut harus baik dan mampu melunasi kewajibannya. Penialaian ini bertujuan untuk melihat kondisi usaha anggota yang dibiayai oleh BMT apakah memiliki prospek yang baik, sehingga resiko pembiayaan bermasalah relatif kecil.

5) Collateral (jaminan). Barang jaminan yang digunakan oleh anggota untuk menanggung pembayaran kembali suatu pembiayaan, apabila anggota tidak dapat melunasi pembiayaan yang dipinjam sesuai dengan jumlah yang diberikan oleh BMT Mikat AlKhidmah. Penilaian ini bertujuan untuk bisa mengkover nilai pembiayaan yang akan diberikan oleh BMT Mikat Al-Khidmah, jika suatu saat terjadi masalah maka jaminan tersebut bisa dijual dan diuangkan untuk melunasi modal pembiayaan yang sudah dipinjamkan. Jika nilai jual jaminan tidak bisa mengkover pembiayaan maka pihak BMT Mikat Al-Khidmah akan mengambil dana di cadangan penghapusan piutang. Dan jika nilai jual jaminan lebih dari pembiayaan yang diberikan maka kelebihannya akan dikembalikan kepada anggota tersebut.

\section{b. Melakukan Proses Penagihan}

Proses ini dilakukan secara berkala dengan sistem door to door. Dalam fasilitas ini pengambilan dan penyetoran ditempat nasabah. Petugas BMT akan melakukan penarikan pembiayaan maupun setoran tabungan. Setiap harinya petugas BMT akan melakukan penarikan tabungan dan pada akhir bulan akan dipotong sebagai pembayaran angsuran. Dalam hal ini akan sangat membantu meminimalkan terjadinya pembiayaan bermasalah.

\section{c. Pemantauan Penggunaan Pembiayaan}

Pihak BMT Mikat Al-Khidmah akan memantau pembiayaan yang sudah disalurkan kepada anggotanya. Pemantauan yang dilakukan BMT Mikat Al-Khidmah yaitu dengan kunjungan waktu yang sudah dijanjikan kepada kedua belah pihak. Tujuan ini agar pihak BMT mengetahui apakah anggota tersebut benar-benar menggunakan dananya tersebut sesuai dengan permohonan semula atau digunakan untuk keperluan lainnya. Bagaimana prospek dan perkembangan usaha yang dijalankan oleh anggota.

Dalam penyelesaian pembiayaan bermasalah, BMT Mikat Al-Khidmah akan melakukan tindakan sebagai berikut:

1) Rescheduling (penjadwalan ulang). Perubahan syarat pembiayaan yang menyangkut jadwal pembayaran dan atau jangka waktu termasuk masa tenggang dan perubahan besarnya angsuran pembiayaan. Tidak semua anggota dapat diberikan kebijakan ini oleh BMT Mikat Al-Khidmah, melainkan hanya kepada anggota yang menunjukkan karakter yang jujur dan memiliki kemauan untuk membayar atau melunasi pembiayaan. Penjadwalan ulang ini dilakukan setelah adanya musyawarah dan kesepakatan dari kedua belah pihak. Dengan adanya penjadwalan ulang ini anggota diberi keringanan waktu untuk menyelesaikan angsuran pembiayaan. 
2) Restructuring (penataan ulang). Cara yang dilakukan jika anggota benar-benar mengalami kesulitan keuangan, seperti anggota terkena musibah bencana alam dan mengalami penyakit berat yang menyebabkan usahanya tidak berjalan lagi. Untuk menyelamatkan usaha anggota agar berkembang kembali dan memenuhi kewajibannya. Hal ini dilakukan oleh BMT dengan cara menambah modal usaha kepada anngota sehingga bisa memperbaiki kegagalan dalam usahanya. Dengan demikian anggota bisa membenahi usahanya dari awal dan pihak BMT akan tetap memantau usahanya tersebut.

3) Penyelesaian melalui jaminan. Cara ini yang dilakukan pihak BMT jika pembiayaan benar-benar tidak bisa diselamatkan dan anggota benar-benar sudah tidak memiliki karakter atau itikad baik untuk mengembalikan pinjamannya, maka petugas BMT Mikat Al-Khidmah melakukan jalan terakhir yaitu dengan menyita barang jaminannya. Jika masih tidak dapat terselesaikan dengan penyitaan barang dalam pembiayaan bermasalah, maka pihak BMT akan melakukan pelelangan barang tersebut. Dan jika nilai jual barang tersebut kurang untuk menutup pembayaran angsuran anggota tersebut, maka kekurangan tersebut akan diambil dari cadangan penghapusan piutang. Jika terjadi kelebihan dalam nilai jual barang tersebut, uangnya akan dikembalikan kepada anggota tersebut (Widianto, 2020).

d. Cara Penyelesaian Pembiayaan Murābahah Bermasalah di BMT Mikat Al-Khidmah

Pemberian pembiayaan yang tertuang dalam suatu perjanjian tidak dapat dilepaskan dari prinsip kepercayaan, yang sering menjadi sumber malapetaka bagi nasabah sehubungan dengan pembiayaan bermasalah. Pembiayaan bermasalah biasanya cenderung untuk diselesaikan apabila tidak diatasi dengan cara yang benar. Menurut peneliti Penyelesaian pembiayaan bermasalah akan lebih efektif apabila dilakukan sejak dini yaitu ketika pembiayaan tersebut sudah teridentifikasi akan mengalami masalah. Penyelesaian pembiayaan bermasalah melalui cara damai dapat dilakukan antara lain dengan keringanan pembayaran tunggakan pokok, penjualan agunan, pengambil alihan aset debitur oleh lembaga keuangan, novasi pembiayaan bermasalah kepada pihak ketiga dengan kompensasi aset perusahaan debitur kepada pihak ketiga. Penyelesaian pembiayaan bermasalah melalui saluran hukum tidak dilakukan oleh semua BMT/KSU, karena penyelesaian pembiayaan bermasalah melalui hukum tergantung kebijakan dari pihak BMT. Namun jika ada BMT yang memakai jalur hukum dalam penyelesaian pembiayaannya, maka antara lain dengan penyelesaian pembiayaan melalui pengadilan negeri, yang mencakup somasi atau peringatan dan gugatan, penyerahan pengurusan kepada Kantor Pelayanan Piutang dan Lelang Negara, permohonan pernyataan kepailitan melalui pengadilan niaga, penyelesaian pembiayaan bermasalah melalui kejaksaaan, penyelesaian pembiayaan dengan mengajukan klaim.

Strategi yang telah digunakan oleh BMT Mikat al-Khidmah Purworejo selama ini telah berjalan dengan baik. Namun masih ada beberapa hal yang perlu diperhatikan dan diperbaiki oleh pihak manajemen BMT. Sedikit mengulas tentang tindakan yang dilakukan BMT dalam penyelamatan pembiayaan bermasalah. Terdapat beberapa faktor yang mengakibatkan hal tersebut dapat terjadi. Pada kenyataan di lapangan prosedur awal yang digunakan adalah pemberitahuan melalui telepon, namun persoalan masih saja muncul ketika nasabah memberikan nomor yang tidak dapat dihubungi. Seperti 
hasil wawancara dengan (Syarif: 2020) selaku karyawan marketing bahwa, beberapa alasan yang didapat pihak BMT, yang pertama adalah terdapat sebagian nasabah yang telah mengganti nomor telepon mereka, namun selanjutnya nasabah tidak memberitahukan kembali nomor terbaru mereka kepada pihak BMT, yang kedua faktor kesengajaan dari nasabah itu sendiri untuk tidak mengangkat telepon atau membalas sms/wa dari petugas. Hal inilah yang membuat petugas kesulitan untuk menggunakan prosedur pertama tersebut.

Selanjutnya prosedur yang kedua yaitu pemberian surat penagihan. Menurut peneliti, pada kenyataan di lapangan sebagian besar prosedur ini tidak memberikan hasil yang maksimal, karena alasannya hanya sebuah surat pemberitahuan dan tidak berdampak terlalu besar untuk nasabah.

Tetapi catatan yang terbaik adalah pihak BMT selalu mengedepankan asas kemanusiaan dan menjauhkan kekerasan dalam melakukan penagihan terhadap nasabah yang mengalami masalah.

Selanjutnya, ketika prosedur tersebut tidak mendapatkan hasil prosedur yang selanjutnya adalah penagihan oleh managemen BMT, yaitu dengan cara meminta nasabah yang belum mampu membayar tunggakannya untuk datang ke kantor BMT Mikat Al-Khidmah. Adapun tujuannya adalah untuk melakukan perundingan dengan nasabah yaitu melalui Rescheduling (penjadwalan ulang), Reconditioning (Persyaratan ulang), dan Restructuring (penataan ulang). Menurut peneliti ketiga cara inilah yang menunjukkan hasil yang menggembirakan.

\section{Analisis Pembiayaan Murābahah Bermasalah di Bmt Mikat Al-Khidmah}

Dalam pengertian pembiayaan berdasarkan Standar Operasional Prosedur Koperasi Jasa Keuangan Syariah dan Unit Jasa Keuangan Syariah, Peraturan Menteri Koperasi dan Usaha Kecil dan Menengah Republik Indonesia nomor : 11/PER/M.KUKM/XII/2017 adalah kegiatan penyediaan dana untuk investasi atau kerjasama permodalan antara koperasi dengan anggota, calon anggota, koperasi lain dan atau anggotanya yang mewajibkan penerima pembiayaan itu untuk melunasi pokok pembiayaan yang diterima pada pihak koperasi sesuai akad disertai dengan pembayaran sejumlah bagi hasil dari pendapatan atau laba dari kegiatan yang dibiayai atau penggunaan dana pembiayaan tersebut.

\section{Kategori Pembiayaan Murābahah Bermasalah}

Pembiayaan bermasalah adalah suatu hal yang tidak di inginkan oleh lembaga keuangan manapun termasuk BMT. Pembiayaan murābahah bermasalah terjadi ketika anggota pembiayaan mengingkari janji untuk membayar angsuran pembiayaan atau tidak membayar seluruh utang pembiayaan beserta bagi hasil pada saat jatuh tempo, sehingga terjadi keterlambatan pembayaran atau sama sekali tidak ada pembayaran. Pembiayaan bermasalah dilihat dari segi produktivitasnya dalam kemampunnya menghasilkan pendapatan bagi bank sudah berkurang atau menurun dan bahkan mungkin sudah tidak ada lagi. Dari segi bank itu sendiri, sudah tentu mengurangi pendapatan, memperbesar biaya cadangan, yaitu PPAP (Penyisihan Penghapusan Aktiva Produktif) (Djamil, 2012: 66).

Adapun yang termasuk dalam kategori pembiayaan muräbahah bermasalah di BMT Mikat Al-Khidmah telah dikelompokkan berdasarkan kolektibitasnya, diantaranya: 
a. Kurang lancar. Pembiayaan dikatakan kurang lancar apabila terdapat tunggakan pokok maupun margin selama 1-3 bulan.

b. Diragukan. Pembiayaan dikatakan kurang lancar apabila terdapat tunggakan pokok maupun margin selama 4-6 bulan

c. Macet. Pembiayaan dikatakan macet apabila terdapat tunggakan pokok maupun margin lebih dari 6 bulan.

Hal ini dibuat agar mempermudah BMT Mikat Al-Khidmah dalam mengambil tindakan dalam hal pencegahan dan penyelesaianya.

\section{Penyebab Pembiayaan Bermasalah}

Seperti halnya di BMT Mikat Al-Khidmah yang memiliki masalah, yaitu pembiayaan murābahah bermasalah. Setiap penyaluran pembiayaan tentu mengandung resiko, karena keterbatasan kemampuan manusia untuk memprediksi masa yang akan datang dan situasi dan kondisi lingkungan yang cepat berubah-ubah. Dalam hal ini peneliti akan memaparkan tentang penyebab terjadinya pembiayaan bermasalah di BMT Mikat Al-Khidmah:

a. Dari pihak BMT Mikat Al-Khidmah

1) Analisa pembiayaan kurang teliti dan kurang cermat dalam menganalisis dan menilai data calon anggota sehingga data yang di analisis tidak sesuai dengan keadaan calon nasabah yang sebenarnya.

2) Penyelesaianya terhadap pembiayaan yang ada gejala bermasalah tidak diterapkan secara dini dan tepat waktu. Sehingga pembiayaan bermasalah itu mudah terjadi di BMT.

3) Terlalu berobsesi pada pencapaian target, sehingga ketika calon anggota mengajukan pembiayaan tidak dilakukan dengan cermat dan hati-hati.

4) Pendidikan dan pengalaman di bagian pembiayaan sangat terbatas. Sehingga dalam pemberian pembiayaan menjadikan salah sasaran dalam mencari calon penerima pembiayaan.

b. Dari pihak Nasabah/Anggota

1) Terjadi kebangkrutan atau penurunan usaha yang dikelola oleh anggota atau nasabah. Hal ini menjadi salah satu penyebab masalah dalam membayar angsuran kepada pihak BMT dan perubahan kondisi ekonomi yang menyebabkan menurunnya daya beli masyarakat, sehingga usaha yang dikelola anggota menjadi terhambat dalam produksinya. Jika sudah terjadi seperti ini BMT akan menjual assetnya sesuai dengan kesepakatan bersama.

2) Data dan informasi yang diberikan kepada petugas BMT adalah palsu atau dengan memanipulasi data keuangan anggota. Pihak BMT akan melakukan penyelidikan kembali data-data dan informasi nasabah dari tetangganya atau teman terdekat.

3) Anggota mengalami PHK oleh perusahaan tempat dia bekerja, hal ini mengakibatkan tersendatnya dalam pembayaran angsuran dan sering mengajukan permintaan penundaan pembayaran. BMT akan melakukan musyawarah dengan nasabah secara kekeluargaan.

4) Anggota mengalami musibah seperti kematian, kebanjiran, kebakaran, gunung meletus, ini merupakan suatu faktor diluar usaha anggota yang tidak dapat diprediksi sebelumnya. Pihak BMT akan melakukan musyawarah, setelah itu penataan ulang 
untuk menyelamatkan usaha anggota agar berkembang kembali dan memenuhi kewajibannya (Akhadi: 2020).

\section{Analisis Hukum Islam terhadap Penyelesaian Pembiayaan Murābahah Bermasalah di BMT Mikat Al-Khidmah Kabupaten Purworejo}

1. Silaturahim. Silaturahim yang dilakukan oleh petugas BMT Mikat Al-Khidmah ini bertujuan untuk mencari informasi tentang permasalahan yang dihadapi oleh nasabah, sekaligus memberikan solusi dan semangat kepada nasabah untuk bisa mengangsur kembali sisa kewajibannya. Anjuran untuk bersilaturahmi terhadap sesama manusia juga dijelaskan dalam al-Qur'an surat An-nisa' ayat 1 sebagai berikut:

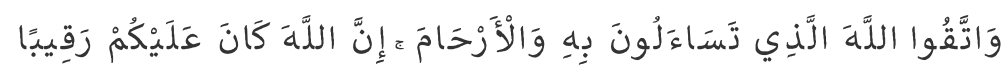

Artinya: Dan bertakwalah kepada Allah yang dengan (mempergunakan) nama-Nya kamu saling meminta satu sama lain, dan (peliharalah) hubungan silaturrahim. Sesungguhnya Allah selalu menjaga dan mengawasi kamu.(Qs. An-nisa': 1)

Dari ayat diatas dijelaskan bahwa Allah menyuruh umatnya untuk selalu menjaga hubungan baik (bersilaturahim) terhadap sesama manusia karena bagaiamanapun manusia saling membutuhkan. Hal ini juga dilakukan oleh BMT Mikat Al-Khidmah dengan tujuan menjalin hubungan yang baik dengan para nasabah serta membantu nasabah untuk mencari solusi bersama. Karena dengan bersilaturrahim ke rumahrumah nasabah yang bermasalah maka petugas BMT akan mengerti apa yang sedang dialami oleh nasabah-nasabah tersebut dan bisa bernegoisiasi dalam hal mencari jalan keluarnya.

2. Perpanjangan Jangka Waktu. Perpanjangan jangka waktu angsuran yang diberikan oleh BMT Mikat Al-Al-Khidmah kepada nasabah yang mengalami pembiayaan bermasalah adalah salah satu cara BMT dalam membantu nasabah yang mengalami kesulitan ekonomi. Hal ini sesuai dengan firman Allah Surat al-Baqarah ayat 280:

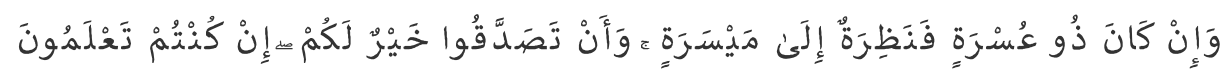

Artinya: Dan jika (orang yang berhutang itu) dalam kesukaran, Maka berilah tangguh sampai dia berkelapangan. Dan menyedekahkan (sebagian atau semua utang) itu, lebih baik bagimu, jika kamu Mengetahui. (QS. al-Baqarah: 280).

Dari ayat diatas dijelaskan bahwa pihak yang berpiutang supaya memberikan kesempatan atau kelonggaran kepada pihak berhutang apabila mengalami kesulitan, dan sungguh mulia mengeluarkan sedekah kepada orang yang sedang dalam kesusahan itu dengan jalan membebaskannya dari utang, baik sebagian maupun keseluruhan. Tetapi pemberian kelonggaran itu hanya diberikan apabila pihak nasabah mengalami kesulitan, bukan karena sebab lain (seperti nasabah mampu membayar tapi enggan untuk membayar). 
Dalam penyelesaian pembiayaan bermasalah tahap perpanjangan jangka waktu yang diberikan oleh BMT kepada Nasabah ini sesuai dengan sebab dianjurkannya kelonggaran yang dijelaskan dalam surat al-Baqarah ayat 280 tersebut, yaitu dengan sebab pihak nasabah sedang mengalami kesulitan. Jadi dalam hal ini pihak BMT Mikat Al-Khidmah memberikan keringanan dalam hal jangka waktu angsuran kepada nasabah yang benar-benar mengalami kesulitan.

3. Eksekusi Agunan dan Pelelangan. Eksekusi dan pelelangan agunan yang dilakukan oleh BMT Mikat Al-Khidmah merupakan salah satu cara untuk mengembalikan modal dan mengurangi kerugian yang akan berpengaruh terhadap kesehatan keuangan BMT. Langkah ini diambil setelah melalui beberapa tahap dan tidak adanya titik temu antara pihak BMT dengan nasabah. Hal ini sesuai dengan fatwa DSN-MUI. Dalam penyelesaian pada tahap eksekusi agunan dan pelelangan agunan yang dilakukan oleh BMT Mikat AlKhidmah sesuai dengan fatwa DSN No. 47/2005 tentang penyelesaian piutang murābahah bagi nasabah yang tidak mampu membayar dengan ketentuan sebagai berikut:

a. Obyek murābahah atau jaminan lainnya dijual oleh nasabah kepada atau melalui LKS dengan harga pasar yang di sepakati.

b. Nasabah melunasi sisa hutangnya kepada LKS dari hasil penjualan.

c. Apabila penjualan melebihi sisa hutang maka LKS mengembalikan sisanya kepada nasabah.

d. Apabila nasabah tidak mampu membayar sisa hutangnya, maka LKS dapat membebaskanya.

Jika salah satu pihak tidak menunaikan kewajibannya atau jika terjadi perselisihan di antara pihak-pihak terkait, maka penyelesaiannya dilakukan melalui Badan Arbitrase Syariah Nasional setelah tidak tercapai kesepakatan melalui musyawarah. Dalam konsep ta'zir, debitur yang sengaja tidak mau membayar utangnya, padahal dia mampu, salah satunya bisa diterapkan hukuman ta'zir atau eksekusi jaminan. Eksekusi agunan dan pelelangan yang dilakukan oleh BMT telah melalui prosedur yang berlaku mulai dari tahap I,II,III sampai kepada ekseskusi. Dalam tahap eksekusi ini BMT Mikat Al-Khidmah tidak langsung melelang agunan yang disita, melainkan memberikan kesempatan yang terahir kepada nasabah untuk bisa melunasi sisa kewajibannya. Ketika dalam pelenangan masih ada sisa maka akan dikembalikan kepada nasabah tersebut, langkah-langkah eksekusi tersebut secara umum sesuai dengan ketentuan fatwa DSN No 47/2005 di atas.

4. Penghapusan Piutang. Penghapusan piutang ini merupakan langkah terakhir yang diambil oleh BMT Mikat Al-Khidmah dalam menyelesaiakan pembiayaan bermasalah. Hal ini sesuai dengan firman Allah SWT dalam Surat Al-Baqarah ayat 280. Setelah memberikan kelonggaran waktu pembayaran, tambahan dana, dan eksekusi jaminan maka langkah terahir yang dilakukan oleh BMT Mikat Al-Khidmah adalah melakukan pengahapusan piutang, hal ini sesuai dengan ajaran Islam, yaitu menyedekahkan (sebagian atau semua utang) itu. Menurut Handi Suhendi dalam bukunya fiqih muamalah mengatakan bahwa langkah-langkah penyelesaian seseorang yang tidak mampu membayarnya yaitu, pertama diberi penundaan waktu pembayaran 
(perpanjangan jangka waktu peminjaman), apabila dalam perpanjangan waktu tidak mampu melunasi maka maafkanlah dia dan anggap sebagai shadaqah. Hal ini sesuai dengan hadits Nabi SAW, beliau bersabda:

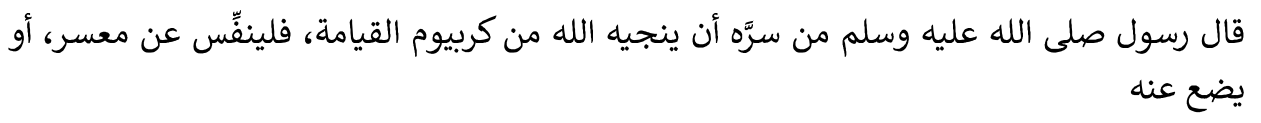

Artinya: "Rasulullah Saw bersabda: Barang siapa ingin diselamatkan oleh Allah dari kesusahan-kesusahan hari Kiamat maka hendaklah dia memberi tangguh kepada orang yang dalam kesukaran atau menghapuskan utangnya. " (Riwayat Muslim). (Suhendi, 2002: 302).

Dari Hadits di atas jelaslah bahwa orang yang memberikan pertolongan kepada orang-orang yang berhutang dan menghapuskan hutang itu maka akan diberi pertolongan dihari kiamat nanti suatu langkah baik yang dilakukan oleh BMT Mikat Al-Khidmah dan sangat membantu terhadap nasabah yang mengalami kesulitan. Walaupun pada praktiknya BMT Mikat Al-Khidmah belum pernah melakukan langkah penghapusan piutang ini. Dari analisis tersebut terlihat bahwa penanganan pembiayaan muräbahah bermasalah di BMT Mikat Al-Khidmah telah sesuai dengan prinsip Syariah dan sesuai dengan Peraturan Menteri Koperasi dan Usaha Kecil dan Menengah Republik Indonesia nomor: 11/PER/M.KUKM/XII/2017 tentang pelaksanaan kegiatan usaha simpan pinjam dan pembiayaan Syariah. Sebagaiamana yang dijelaskan pada bagian Kegiatan Bisnis (Tamwil) Pinjaman dan Pembiayaan Syariah diatur sebagaimana yang tertuang pada pasal 24 ayat ke 1 (satu) yang berbunyi "Pelaksanaan pemberian pinjaman dan pembiayaan Syariah oleh KSPPS dan USPPS Koperasi wajib memperhatikan prinsip pemberian pinjaman dan pembiayaan Syariah yang sehat".

\section{SIMPULAN}

Dari pembahasan yang Peneliti paparkan tentang Tinjauan hukum Islam terhadap penyelesaian pembiayaan bermasalah dapat disimpulkan bahwa penyelesaian pembiayaan murābahah bermasalah di BMT Mikat Al-Khidmah telah memenuhi prosedur dan sesuai dengan hukum Islam. Hal ini dapat dilihat dari bentuk dan cara penyelesaian mengacu pada dalil-dalil baik dalam Al-Qur'an maupun Hadits dan telah sesuai dengan Peraturan Menteri Koperasi dan Usaha Kecil dan Menengah Republik Indonesia nomor: 11/PER/M.KUKM/XII/2017 tentang pelaksanaan kegiatan usaha simpan pinjam dan pembiayaan Syariah. Sebagaiamana yang dijelaskan pada bagian Kegiatan Bisnis (Tamwil) Pinjaman dan Pembiayaan Syariah diatur sebagaimana yang tertuang pada pasal 24 ayat ke 1 (satu) yang berbunyi "Pelaksanaan pemberian pinjaman dan pembiayaan Syariah oleh KSPPS dan USPPS Koperasi wajib memperhatikan prinsip pemberian pinjaman dan pembiayaan Syariah yang sehat". 


\section{DAFTAR PUSTAKA}

Ascarya. (2007). Akad dan Produk Bank Syariah. Jakarta: PT Raja Grafindo Persada.

Djamil, Faturrahman. (2012). Penyelesaian Pembiayaan Bermasalah di Bank Syariah. Jakarta: Sinar Grafika. cet. 1.

Ibrahim. (2018). Metodelogi Penelitian Kualitatif. Bandung: Alfabeta.

Kementerian Agama RI, Al-Qur'an Dan Terjemahnya.

Nawawi, Ismail. 2012. Fikih Muamalah Klasik dan Kontemporer: Hukum Perjanjian, Ekonomi, Bisnis, dan Sosial. Bogor: Ghalia Indonesia.

Ridwan, Muhammad. (2004). Manajemen Baitul Maal Wa Tamwil (BMT). Yogyakarta: UII Press.

Soekanto, Soerjono. (1984). Pengantar Penelitian Hukum. Jakarta: Universitas Indonesia.

Suhendi, Hendi Fiqih. (2002). Muamalah. Bandung: PT. Raja Grafindo Persada.

Syafi'i Antonio, Muhammad. (2001). Bank Syariah dari Teori ke Praktik. Jakarta: Gema Insani.

Wangsawidjaja. (2005). Pembiayaan Bank Syariah. Jakarta: PT Gramedia Pustaka Utama.

Wawancara dengan bapak Zainul Syarif selaku marketing Mikat Al-Khidamah pada tanggal 10 September 2020.

Wawancara dengan Latief Akhadi selaku kepala Cabang BMT Mikat al-Khidmah pada tanggal 10 Agustus 2020.

Wawancara dengan Wahyu Widianto selaku Marketing BMT Mikat al-Khidmah pada tanggal 10 Agustus 2020.

Wiroso. (2005). Jual Beli Murabahah. Yogyakarta: UII Press. 